\title{
DEVELOPMENT OF NORTHERN AUSTRALIA
}

T his presidential address to the Section of Geography and Oceanography at the thirty-seventh annual congress of the Australian and New Zealand Association for the Advancement of Science, Prof. R. H. Greenwood (University of Queensland) analysed the conditions for accelerated development in Northern Australia (Australian Journal of Science, 26; April 1964).

The first point which he emphasized was the necessity for an onlarged market for Australian goods. Since the largest domestic market is in the south-east, and, since Australian transport costs are high, there is no purpose in seeking to replace existing production in the north. Additional markets may be created in four sectors -two domestic and two foreign. The domestic market is being constantly enlarged to keep in line with the increasing Australian population; however, it couldwith benefit to the economy-be increased still mor, by roplacing imports by homo-produced goods. The latter offers the more appealing prospects, but in the main it depends on the ability to pioneer new techniques for the production of tropical crops that are normally labourintensive (rubber, coffee, tea, copra, ete.) and to intensify the search for minerals and oil (which constitutos a particularly large item on the import bill). Overseas markets can be expanded either by seeking new buyers for the conventional products of the north (mainly beef, sugar and minerals), or by innovations such as exploiting newly discovered minerals, or by the large-scale production of tropical grains and other food crops and raw materials for Asian markets. In theory, there is a substantial potential in each of these market sectors. The major problem is high costs, and this is of such significance to the basic proposition that the second condition for accelerated development is the ability to reduce overall production costs, or (and this is not by any means the same thing) to reduce the price charged for goods produced in the north.

There are some ways in which small savings can be mado. It would be an advantage to increase productivity in those parts of the Australian Commonwealth that are nearest to her customers. It is unsatisfactory that Australia should, in a geographical sense, face away from her customers. It is a significantly shorter haul from Darwin to Hong Kong, Madras or London than it is from Melbourne, and the shorter time of the sea voyage may be important for technical reasons as well as cost (for example, in the ability to deliver chilled beef to the United Kingdom). Land would be comparatively cheap and every advantage of large-scale commercial production could be reaped in agriculture. The largest element in the higher cost margin, however, relates to the establishment of essential services-water, power, transport and building -in areas remote from the main centres of production. The capital costs involved in setting the productive machine in motion are high and the benefits dorived would b. long-period, rather than short-period, benefits of a kind which reduce the attractiveness of the proposition to private enterprise. Moreover, public funds available for such capital developments are not unlimited.

This leads to the third condition for development. The benefits of capital investment in the north must be maximized. It would be essential to extract the utmost value from each project. In an area as big as tropical Australia, there is likely to be a moasure of regional dispersal of public expenditure, each item adding different amenities in widely separated districts. The main item of public investment in the north should, however, be carefully planned to provide as many of the prerequisites for diversified development as possible. An ideal model would be the provision of a water storage that could bc used both for irrigation, town supply and power generation to a nearby area with suitable conditions for the cultivation of an industrial crop which could bo processed-at least in part locally--with road access to a nottoo-distant port. Tho anticipated benefits would include the capacity of the original investment to bring about growth of ancillary and dependent activities in an exponential manner and, in particular, to stimulate the growth of small urban communities, the increasing needs of which would create opportunities for additional use of local land, water, power and other services. Such a deceptively simple model is not by any means easily. created. For example, there is the temptation to start with the selection of a suitable dam-site and seo what can be done with its surroundings. Governments in many parts of the world have been prone to build dams first and think of ways of using the water thoy retain afterwards.

The starting-point should be the selection of a crop with carefully evaluated market prospects. The next stage would bo the location of one region in which market surveys indicate that the production of the crop is justified on a large scale. This should be a region with maximum nodality, with country capable of complementary rural production in different districts, with maximum access to a port, roads, railways and other services or with optimum means of creating such access. The logistics of geographical location are of immense importance, and the districts around Rockhampton and Darwin have great possibilities as regards the polarization of new developments. They are natural nodes to which easy lines of communication converge and around which varied resource patterns are disposed. They are of particular significance, as notably Australia lacks such naturally endowed nodal districts. Dam sites should only be looked into after the purpose has been satisfactorily defined of the new developmental scheme and the optimum location for its introduction agreed.

\section{A GREAT PATHOLOGIST AND NATURALIST}

\begin{abstract}
$\mathrm{A}^{\mathrm{D}}$ OLPH LUTZ, one of the world's greatest medical zoologists, was born in Rio de Janeiro in $1855^{*}$. His parents were Swiss, and when they returned to Berne in 1865, Adolph was educated in Switzerland. When his parents later returned to Brazil, Adolph was left behind to go to school in Basle. He had by then already decided

* Adolpho Lutz (1855-1955): Vida e Obra do Grande Cientista Brasileiro. Pp. 55. (Rio de Janeiro: "Comissao do Centenario de Adolphe Lutz", Conselho Pacional de Pesquisas.)
\end{abstract}

to spend his life studying natural history, and in 1874 he began to study medicine at the University of Berne, taking courses also at Leipzig, Strasbourg and Prague, and studying biology as well. In 1879 he received his licence to practise medicine. Already he had published papers on the Cladocera of the neighbourhood of Berne and Leipzig. He went to Vienna and Paris for postgraduate studies, and then returned to Brazil, where he practised medicine from 1882 until 1892 in the province 